\begin{tabular}{llllllll}
$\mathbf{R}$ & $\mathbf{E}$ & $\mathbf{C}$ & $\mathbf{E}$ & $\mathbf{N}$ & $\mathbf{Z}$ & $\mathbf{J}$ & $\mathbf{E}$ \\
\hline
\end{tabular}

VOX PATRUM 19 (1999) t. 36-37

\title{
Ks. Adam K. FIROSZ. Koncepcja katechezy w pismach św. Augus- tyna, Lublin 1999, Redakcja Wydawnictw KUL, ss. 198.
}

Autorzy opublikowanej niedawno polskiej bibliografii katechetycznej za ostatnie pół wieku ${ }^{1}$ wskazali wymownie na brak w polskiej literaturze teologicznej opracowań z zakresu historii katechezy w ogóle, w tym dotyczących katechezy pierwszych wieków chrześcijaństwa w szczególności. Dlatego z uwagą należy przyjąć książkę ks. Adama K. Firosza, poświęconą „określeniu celu, treści, podmiotu i metody katechezy augustyńskiej” (Wstęp s. 33), tym bardziej, że nie jest to pierwsza praca Autora dotycząca zagadnień katechezy okresu patrystycznego $^{2}$. Na tym jednak można skończyć komplementy. Bliższa bowiem analiza treści publikacji nie wytrzymuje konfrontacji z tytułem. Czytelnik ma bowiem prawo oczekiwać, że spotka się z wnikliwą analizą - jak to założył sam Autor we wstępie - teorii i praktyki katechetycznej Biskupa Hippony w analizie głównego dzieła poświęconego tym zagadnieniom, a więc $D e$ catechizandis rudibus (tłum. W. Budzik: Poczatkowe nauczanie religii, w: Św. Augustyn, Pisma katechetyczne, Warszawa 1952, 1-60) oraz w pismach zawierających katechezę chrzcielną, jak na przykład w De Symbolo sermo ad catechumenos (tłum. W. Budzik: Kazanie do katechumenów o wyznaniu wiary, tamże, 61-76) lub w pismach mających na celu umocnienie wiary wierzących, jak w: De agone christiano (tłum. W. Budzik: Chrześcijańska walka, tamże, $228-258)^{3}$.

${ }^{1}$ Por. Bibliografia katechetyczna 1945-1995, oprac. R. Murawski SDB przy współpracy R. Czekalskiego i J. Tochmańskiego, Warszawa 1999.

${ }^{2}$ Por. A. Firosz, Organizacja katechezy w Afryce łacińskiej w epoce św. Augustyna, Lublin 1983 (mps BKUL).

${ }^{3}$ Znawca tego zagadnienia, ks. R. Murawski (Metodyka katechizacji wedtug św. Augustyna, w: W stuzbie człowiekowi. Studium duszpastersko-katechetyczne, Kraków 1991, 158-172) pisze „traktat »De catechizandis rudibus« nie jest jedynym dziełem katechetycznym św. Augustyna. Biskup z Hippony posiadał bardzo bogate doświadczenie katechetyczne. Tej formie pracy dusz- 
Te zagadnienia zostały - niestety - omówione tylko w dwóch ostatnich rozdziałach pracy (s. 127-187) ${ }^{4}$, podczas gdy w trzech pierwszych podjął się Autor rzekomo omówienia tzw. celów katechezy (głównego i szczegółowego) i treści (programu) katechetycznego ${ }^{5}$. Zdecydowaliśmy się na określenie zabiegów Autora około przedstawienia celu i treści katechezy mianem „rzekomych", bo stoją one w wyraźnej opozycji do powszechnie przyjętych w katechetyce znaczeń tych terminów. Wystarczy bowiem sięgnąć do podstawowych podręczników katechetyki, by zrozumieć, jak dalece ks. Firosz rozminął się z ich znaczeniem. Analiza bowiem relacji osobowych, występujących w Trójcy Świętej i historiozbawczej roli każdej z Osób, nie stanowi o celu katechezy ${ }^{6}$. W pewnym sensie zagadnieniem celu zajął się Autor dopiero w rozdziale drugim prezentowanej tu książki, stosując przy tym dość dziwne i oryginalne, ale odpowiadające treści, nazwy form katechezy pisteologicznej, elpidycznej i agapetologicznej (skierowanej ku budzeniu wiary, nadziei i miłości).

W odczytaniu treści książki przeszkadza też stosowanie własnych nazw na określenie od dawna zadomowionych w katechetyce terminów technicznych, na przykład podmiotu katechezy zamiast nie za wiele mówiącej nazwy „środowisko katechetyczne" ${ }^{7}$ itp. Byłoby więc o wiele lepiej, gdyby Ksiądz Firosz zwrócił baczniejszą uwagę i na te - nieliczne wprawdzie - prace, które są $\mathrm{w}$ języku ojczystym i podejmują fundamentalne zagadnienia związane $\mathrm{z}$ tematem anonsowanym w tytule książi ${ }^{8}$. O nich jednak cicho w bogatym spisie bibliograficznym (s. 13-30), w którym Autor, mimo iż pochodzi ze środowiska kulowskiego, nie tylko nie zna poświęconego w większości katechezie patrystycznej 18 tomu „Vox Patrum” (1990), ale i nie cytuje przydatnej bez wątpienia w tej pracy zawartej tam patrystycznej bibliografii katechetycznej ks. S. Lon-

pasterskiej oddawał się przez blisko 40 lat. W jego pismach katechetycznych znajduje swe odbicie zarówno teoria, tj. wnikliwa refleksja teologiczna, jak i długoletnia praktyka. Trzeba mieć na uwadze jeszcze i ten fakt, że Augustyn przed przyjęciem chrztu, tj. od 20 do 32 roku życia był nauczycielem. Dysponował zatem bardzo dużym doświadczeniem dydaktycznym" (tamże s. 158).

${ }^{4}$ W czwartym (Środowisko katechetyczne s. 127-154) i piątym (Zagadnienia metodycznodydaktyczne katechezy s. 155-188).

5 Rozdz. I: Trójca Święta jako alfa, centrum i omega katechezy (s. 37-58); rozdz. II: Jezus Chrystus jako Katechetes Dei (s. 59-91); rozdz. III: Katecheza a credo chrześcijańskie (s. 93-125).

${ }^{6}$ Por. W. Koska, Katechetyka, Poznań 1987, s. 55: „Podstawowym celem katechezy jest więc budowanie i rozwijanie wiary [...]. Z tak rozumianego celu katechezy wynikają pewne konsekwencje [...]. Po pierwsze - określenie celu katechezy jako prowadzenia do dojrzałości w wierze ujawnia całą złożoność procesu katechetycznego, który w ten sposób staje się trudniejszy do przeprowadzenia, skoro nie chodzi w nim wyłącznie o nauczanie prawd religijnych, ale także o doprowadzenie katechizowanych do opierania całej ich egzystencji na Chrystusie. Po drugie - przy tak szeroko ujętym celu katechezy powstaje problem granic działania katechezy".

7 Jest to zresztą tytuł rozdziału IV książki ks. Firosza, w którym omawia zagadnienia wchodzące w zakres tzw. aktywnego podmiotu katechezy (por.: Koska, jw. s. 56-65).

${ }^{8}$ Myślę tu o opracowaniu A. L. Szafrańskiego (Augustyn. IX: Myśl i działalność duszpasterska. EK I 1110-1111) oraz cytowanym w przyp. 3 artykule ks. Murawskiego. 
gosza (ss. 417-432: Polskie i wybrane zagraniczne publikacje o katechezie patrystycznej), przy publikacjach zaś obcojęzycznych zauważa się wiele błędów (np. s. 13; Contra litteros Petiliani; s. 14: De naturae et originae animae; s. 15: De lapsi.).

Marek Marczewski - Lublin

\section{Bibliografia katechetyczna 1945-1995, oprac. Roman MURAWSKI SDB przy współpracy R. Czekalskiego i J. Tochmańskiego, Warsza- wa 1999, Wydawnictwo Akademii Teologii Katolickiej, ss. 343.}

Dzięki studentom katechetyki Akademii Teologii Katolickiej oraz Naukowego Koła Katechetyki tej uczelni otrzymaliśmy wspaniały dar: polską bibliografię katolickich publikacji katechetycznych za ostatnie półwiecze (19451995). Pracami, które trwały kilka lat, kierował ks. Roman Murawski, profesor katechetyki, wychowawca wielu pokoleń teologów i katechetów. Pod jego też kierunkiem praca ta została opublikowana. Nie trzeba udowadniać wartości i wagi tego przedsięwzięcia właśnie dziś, gdy w zalewie informacji każdy z podejmujących pracę zawodową lub naukową jako teolog czy katecheta oczekuje bibliografii dziedzinowych, które, dzięki dobrze opracowanemu podziałowi przedmiotu, pomogą szybko zorientować się w literaturze.

Dokonano gigantycznej kwerendy, nie tylko ze względu na okres czasu, ale i liczbę periodyków, z których czerpano informacje. W omawianym spisie zawarto 5. 400 opisów bibliograficznych w s t u (!) działach przedmiotowych: „Nasza bibliografia dzieli się na dziesięć głównych działów, każdy z nich zaś na dziesięć poddziałów [...]. Ze względu na to, że wiele pozycji kwalifikowało się jednocześnie do dwóch lub więcej działów, zostały one w nich powtórzone" (Wstęp s. 9). Spisem nie objęto ,publikacji poświęconych katechezie, publikowanych na łamach codziennych gazet, tygodników, np. »Niedzieli«, »Gościa Niedzielnego«, »Tygodnika Powszechnego« itp., choć z pewnością niektóre spośród nich zasługiwałyby na zamieszczenie w naszej bibliografii" (tamże s. 10). Na marginesie dodajmy, że bibliograficznym wykazem nie objęto też „Vox Patrum”. Tym samym pominięto 10 artykułów wygłoszonych podczas sympozjum na temat „Katechezy patrystycznej” (10:1990 z. 18 s. 57-156) oraz wybraną bibliografię polskich i obcych publikacji poświęconych katechezie patrystycznej (tamże s. 417-432) w opracowaniu ks. S. Longosza.

Anonsowaną tu Bibliografię podzielono na dziesięć głównych działów. Są to: 0. Dokumenty katechetyczne. Programy. Podręczniki. Regulacje prawne; 1. Fundamentalne problemy katechezy; Historia katechezy; 2. Treść kateche$z y ; 3$. Katecheza $w$ innych krajach $i$ innych wyznaniach; 4 . Rodzaje katechezy; 5. Podmiot katechezy: katecheta i katechizowany; 6. Środowisko kateche- 